\title{
Stress in medical patients
}

Stavros Samolis

From $1^{\text {st }}$ International Congress on Neurobiology and Clinical Psychopharmacology and European

Psychiatric Association Conference on Treatment Guidance

Thessaloniki, Greece. 19-22 November 2009

It has been observed that the majority of medical patients demonstrate psychological distress (64\%).A lot of studies have examined the prevalence of anxiety and depression among several categories of medical patients such as: cardiovascular, general surgery, infectious and neurovascular patients.

Another finding is that the prevalence of anxiety and depression in hospitalized medical patients is high, occurs mainly in women, and no relation to illness severity is observed. Anxiety and depression are associated with both illness perception of greater severity and less improvement

Several studies indicate a relationship among depression, anxiety, pain and hospitalization. Depression has a bidirectional relationship with cardiovascular disease, and it is observed in HIV-positive individuals, in cancer patients and it often complicates chronic pain.

Other findings suggest that there is consistently high prevalence rates of depression associated with negative medical, functional, and psychosocial outcomes in hospitalized, medically ill, older adults

Screening for anxiety and depression should be included in the clinical interview carried out by the nurse or the doctor at the moment of admission to the ward.

Submit your next manuscript to BioMed Central and take full advantage of:

- Convenient online submission

- Thorough peer review

- No space constraints or color figure charges

- Immediate publication on acceptance

- Inclusion in PubMed, CAS, Scopus and Google Scholar

- Research which is freely available for redistribution

Submit your manuscript at www.biomedcentral.com/submit 